\title{
The effect of growth substrate and fertilizer on the growth and vesicular-arbuscular mycorrhizal infection of three hosts
}

\author{
Mauritz VestBerg
}

\begin{abstract}
VESTBERG, M. 1992. The effect of growth substrate and fertilizer on the growth and vesicular-arbuscular mycorrhizal infection of three hosts. Agric. Sci. Finl. 1: 95-105. (Agric. Res. Centre of Finland, Laukaa Research and Healthy Plant Unit, Juntula, SF-41340 Laukaa, Finland.)

The effect of growth substrate in combination with two compound fertilizers or bone meal on the vesicular-arbuscular mycorrhizal (VAM) infection and growth of micropropagated strawberry (Fragaria $\mathrm{x}$ ananassa Duch.) and arctic bramble (Rubus arcticus $\mathrm{L}$.), as well as maize (Zea mays $\mathrm{L}$.) was studied in pot experiments. With all test plants, sand fertilized with bone meal was superior to the richer peat-based substrates in initiating rapid VA mycorrhizal infection and sporulation of the VAM fungi used. A fertilizing regime yielding plants of a sufficient size, which at the same time are mycorrhizal, is suggested.
\end{abstract}

Key words: Vesicular-arbuscular mycorrhiza, growth substrate, fertilizer, micropropagated strawberry, micropropagated arctic bramble, maize

\section{Introduction}

Most plants of economic value are naturally associated with vesicular-arbuscular (VA) fungi (HARLEY 1965). Strawberry is reported to benefit from VA mycorrhizae when the availability of phosphorus (P) is limited (DAFT and OKUSANYA 1973, Holevas 1966), but also under standard cultivation conditions in fields with high levels of available soil P (DUNNE and FITTER 1989, WERNER et al 1990). The benefits of inoculating micropropagated or certified stock plants of strawberry are stressed by KIERNAN et al (1984), ROBERTSON et al. (1988) and CHAVEZ and FERRERA-CERRATo (1990). In field experiments, maize showed great increases in shoot dry matter after inoculation with VAM (KHAN 1972). DAFT (1991) observed a nearly $100 \%$ growth increase of maize seedlings after VAM inoculation in sparce stands, but no discernible effects in very dense stands. DAFT and
OKUSANYA (1973) found VAM inoculation especially to increase the number of vascular bundles and also to stimulate pollen development in maize. KothARI et al. (1990), on the other hand, reported that VAM inoculation of maize had no influence on the shoot dry weight, but increased the area and dry weight of leaves by $30 \%$. Simultaneously they observed, however, a $16 \%$ decrease of root dry weight and a $31 \%$ decrease of root length. No studies have been conducted on the VA mycorrhizae of arctic bramble.

The most outstanding effect of VA mycorrhiza on plant growth is the enhanced phosphorus uptake in soils or growth substrates of low phosphorus availability (MOSSE 1986, COOPER 1982, FITTER 1988, DUNNE and FITTER 1989). However, vesicular-arbuscular fungi may thrive also in soils of high soil fertility (GERDEMANN 1970), or in soils amended with $\mathrm{P}$ up to $160 \mathrm{mg} / \mathrm{kg}$ soil as was observed by KIERNAN et al. in maize (1984). 
The aim of this investigation was to study the effect of VA mycorrhiza inoculation on strawberry, maize and arctic bramble growing on sandy or peaty substrates and fertilized with bone meal or mineral compound fertilizers. Further considerations include the nutrient level of a growth substrate required for adequate plant growth and mycorrhizal infection. All experiments were conducted as pot experiments in the glasshouse.

\section{Material and methods}

\section{Experimental designs and practical performance}

To study the effect of substrate, fertilization and VAM inoculation on growth and VAM infection in three hosts, four pot experiments were carried out in the glasshouse. All plants were cultivated in plastic Vefi-pots $(2.5 \mathrm{dl})$, which were placed on top of an approx. $2 \mathrm{~cm}$ layer of wet vermiculite. During the experiments, watering was done to the vermiculite substrate. Three experiments (nos 1, 3 and 4) were of a split-plot design, while experiment 2 was a randomized block experiment. The number of replications varied from four to six.
VAM fungi used, the duration of the experiments and the glasshouse minimum and maximum temperatures are shown in Table 1.

\section{Growth substrates and fertilizers}

The basic growth substrates used in the experiments were fertilized light sphagnum peat (Vapo B1 or B2, Finland), unfertilized sphagnum peat (Vapo, Finland), vermiculite (3-V, Vermipu Finland) and sand. The content of N, P and K in peat $\mathrm{B} 1$ were 96,72 and $144 \mathrm{mg} / \mathrm{l}$ sub-strate, respectively, peat B2 144, 108 and $216 \mathrm{mg} / 1$, respectively, and in peat fertilized with a compound peat fertilizer (1IN-11P-20K, Kemira) $55 \mathrm{mg}$, $55 \mathrm{mg}$ and $100 \mathrm{mg} / \mathrm{l}$ substrate, respectively. The basic substrates were used steam sterilized (three times on successive days, $1 \mathrm{~h} ., 100^{\circ} \mathrm{C}$ ) or unsterilized. The amount of soluble minerals present in the growth substrates after steam sterilization was not determined.

All experiments had the same fertilizer treatments except experiment 4 in which no extra fertilizers were applied to the growth substrates. In one fertilizer (bone meal, Kemira), the phosphorus was in a slowly soluble form. Pots given

Table 1. Experiments conducted to establish the effect of substrate and fertilization on VAM infection and plant growth in three different crops.

\begin{tabular}{|c|c|c|c|c|c|c|}
\hline \multirow{2}{*}{$\begin{array}{l}\text { Number and aim of } \\
\text { experiment }\end{array}$} & \multirow{2}{*}{$\begin{array}{l}\text { Plants } \\
\text { used }\end{array}$} & \multirow{2}{*}{$\begin{array}{l}\text { VAM fungi } \\
\text { used }\end{array}$} & \multirow{2}{*}{$\begin{array}{l}\text { Repli- } \\
\text { cations }\end{array}$} & \multirow[b]{2}{*}{ Duration } & \multicolumn{2}{|c|}{ Temperature, ${ }^{\circ} \mathrm{C}$} \\
\hline & & & & & Min. & \\
\hline $\begin{array}{l}\text { 1. Effect of substrate } \\
\text { and fertilization }\end{array}$ & $\begin{array}{l}\text { Straw- } \\
\text { berry }\end{array}$ & $\begin{array}{l}\text { Glomus } \\
\text { mosseae }\end{array}$ & 6 & $\begin{array}{l}18 \text { January } \\
-27 \text { March } \\
1990\end{array}$ & 17.6 & 30.6 \\
\hline $\begin{array}{l}\text { 2. Effect of fertili- } \\
\text { zation }\end{array}$ & $"$ & $"$ & & $\begin{array}{l}25 \text { January } \\
-18 \text { April } \\
1990\end{array}$ & 18.2 & 30.6 \\
\hline $\begin{array}{l}\text { 3. Effect of liming } \\
\text { and fertilization }\end{array}$ & Maize & $"$ & 4 & $\begin{array}{l}29 \text { January } \\
-22 \text { May } \\
1990\end{array}$ & 18.2 & 31.0 \\
\hline 4. Effect of substrate & $\begin{array}{l}\text { Arctic } \\
\text { bramble }\end{array}$ & $\begin{array}{c}\text { G. Mosseae } \\
\text { Glomus spp. } \\
\text { - isolate } 2 \\
\text { - isolate } 3 \\
\text { - isolate } 4\end{array}$ & 5 & $\begin{array}{l}10 \text { January } \\
-24 \text { July } \\
1990\end{array}$ & 15.5 & 35.7 \\
\hline
\end{tabular}


bone meal were also given a phosphorus-free Hewitt solution (HEwITT 1952) once a week, starting two weeks after onset of the experiment. Two compound mineral fertilizers, both at two concentrations, were also used in the experiments. "Puutarhan Y-2" (7N-5P-15K, Kemira) was a solid fertilizer, while "Puutarhan täyslannos" (14N-5P$21 \mathrm{~K}$, Kemira) was applied as a liquid fertilizer once a week. Table 2 shows the calculated amounts of $\mathrm{P}$ per liter of growth substrate at different fertilizer applications. Sand and unfertilized peat substrates were given dolomite lime (Saxo OY) 5 $\mathrm{g} / \mathrm{l}$ substrate.

\section{Plants}

Micropropagated plantlets of strawberry (Fragaria $\mathrm{x}$ ananassa Duch.) 'Senga Sengana' were used as test plants in experiment 1 and 2. An Fl hybrid of maize (Zea mays L.) 'North star' was used in experiment 3 and in experiment 4 micropropagated plantlets of arctic bramble (Rubus arcticus L.) 'Mespi' and 'Pima' were used.

\section{VAM inoculation}

The VAM fungi used were Glomus mosseae (Nicol. \& Gerd.) Gerd. \& Trappe supplied by the Rothamsted experimental station and Glomus spp. isolates nos 2,3 and 4 from our own collection. The inocula were produced by growing the VA mycorrhizal fungi for four months in maize roots in sand cultures of low phosphorus contents. Each inoculum was a mixture of infected maize root pieces with adhering sand, hyphae and spores. Micropropagated plantlets of strawberry and pregerminated seeds of maize were inoculated with $1 \mathrm{ml}$ of inoculum placed into their planting hole. A thin layer of the inoculum, $3.5 \mathrm{ml} /$ pot, was placed in the middle of the pots where the arctic brambles were planted.

\section{Observations}

Growth response was evaluated by the following criteria:

- Shoot dry weight

- Percentage of plant survival (arctic bramble)

- Plant height (maize)

Table 2. The amount of phosphorus in different growth substrates after applications of fertilizers.

\begin{tabular}{|c|c|c|c|c|c|c|}
\hline \multirow{3}{*}{$\begin{array}{l}\text { Growth } \\
\text { Substrate }\end{array}$} & \multicolumn{6}{|c|}{ Amount of $\mathrm{P}, \mathrm{mg} / \mathrm{l}$ growth substrate } \\
\hline & \multirow{2}{*}{$\begin{array}{l}1 . \\
\text { Unfer- } \\
\text { tili- } \\
\text { zed }\end{array}$} & \multirow{2}{*}{$\begin{array}{l}2 . \\
\text { Bone } \\
\text { meal } \\
+ \text { Hewitt }\end{array}$} & \multicolumn{2}{|c|}{$\begin{array}{l}3 . \quad 4 . \\
\text { Puutarhan } \\
\text { Y2 }\end{array}$} & \multicolumn{2}{|c|}{$\begin{array}{l}5 . \quad 6 . \\
\text { Puutarhan } \\
\text { täyslannos }\end{array}$} \\
\hline & & & $0.5 \mathrm{~g}$ & $1.5 \mathrm{~g}$ & $0.05 \%$ & $0.1 \%$ \\
\hline A. Unsterilized sand & - & 79 & 25 & 75 & 25 & 50 \\
\hline B. Sterilized sand & - & 79 & 25 & 75 & 25 & 50 \\
\hline $\begin{array}{l}\text { C. Peat (B1)+vermiculite } \\
\qquad \begin{array}{l}+ \text { sand, sterilized }(8: 1: 1)\end{array}\end{array}$ & 58 & 137 & 83 & 133 & 83 & 108 \\
\hline $\begin{array}{l}\text { D. Raw peat+vermiculite } \\
\begin{array}{l}+ \text { sand, basic fertilized } \\
\text { and sterilized }(8: 1: 1)\end{array}\end{array}$ & 44 & 123 & 69 & 119 & 69 & 94 \\
\hline E. As D., but $(5: 0: 5)$ & 27 & 106 & 52 & 102 & 52 & 77 \\
\hline $\begin{array}{l}\text { F. Peat (B2)+vermiculite } \\
\qquad \begin{aligned}+ \text { sand, unsterilized }(8: 1: 1)\end{aligned}\end{array}$ & 86 & 165 & 111 & 161 & 111 & 136 \\
\hline $\begin{array}{l}\text { G. Peat (B2)+vermiculite } \\
+ \text { sand, sterilized }(8: 1: 1)\end{array}$ & 86 & 165 & 111 & 161 & 111 & 136 \\
\hline
\end{tabular}


- Number of runners (strawberry)

- Length of leaf stalk (strawberry)

The percentage of infected root was determined (experiment 4) by the gridline intersect method (Giovannette and Mosse 1980). VAM infection was also estimated from the abundance of spores (experiments 1-4). A representative $50 \mathrm{ml}$ root and soil sample from each pot was thoroughly washed in running tap water. The occurrence of spores was evaluated on a rating scale of $0-5$ as follows:

$0=$ No infection

$1=$ Very poor infection, $1-5$ spores $/ 50 \mathrm{ml}$ substrate

$2=$ Poor to moderate infection, approx. 5-20 spores/ $50 \mathrm{ml}$ substrate

$3=$ Moderate infection, $20-$ several hundred spores/ $50 \mathrm{ml}$ substrate

$4=$ Abundant infection, spores abundantly

$5=$ Very abundant infection

\section{Results}

\section{Experiment 1}

Strawberries growing on unsterilized peat substrate (substrate F), where the content of phosphorus varied between 86 and $165 \mathrm{mg} / \mathrm{l}$ substrate, had no VAM sporulation whatsoever after 68 days. When the same substrate was steam sterilized (substrate G), a few spores were observed in the unfertilized (86 P) and in the 7N-5P-15K (86 and $111 \mathrm{P})$ fertilized treatments. In unsterilized sand (substrate A), Glomus mosseae sporulated very abundantly when bone meal + Hewitt solution was used as fertilizer (79 P). Poor to moderate sporulation occurred in the unfertilized treatment. In treatments with the compound fertilizer $7 \mathrm{~N}-5 \mathrm{P}$ $15 \mathrm{~K}$ at two concentrations ( 25 and $75 \mathrm{P})$, only a very poor sporulation was observed (Fig. 1).

The shoot dry weight of strawberry correlated negatively with the occurrence of spores of $G$. mosseae. Strawberry grew best on average on the peat-based substrate $\mathrm{F}$ and poorest on the sand substrate A (Fig. 1). On unsterilized peat substrate the highest dry weights of strawberry, 2.98 and
$3.00 \mathrm{~g} /$ plant, were achieved with bone meal + Hewitt solution and compound liquid fertilizer $15 \mathrm{~N}-15 \mathrm{P}-21 \mathrm{~K}$, respectively. The dry weights were on sterilized peat, 2.01 and $1.59 \mathrm{~g} /$ plant, respectively. On unsterilized sand substrate, however, the liquid compound fertilizer, at concentrations of $0.05 \%$ and $0.1 \%$, was superior to the other fertilizer treatments (Fig. 1).

\section{Experiment 2}

When strawberry was growing on steam sterilized sand (substrate B) spores of $G$. mosseae were detected in all fertilizer treatments after 83 days. As in experiment 1 , spores occurred most abundantly when bone meal + Hewitt solution were used as fertilizer (79 P). A moderate number of spores were found also in unfertilized pots despite the extremely poor growth in these pots. The compound fertilizer $7 \mathrm{~N}-5 \mathrm{P}-15 \mathrm{~K}(0.5 \mathrm{~g} / 1$ sand, $25 \mathrm{P})$ also gave a moderate number of spores, while in the rest of the treatments the occurrence was very low. The highest dry weights of strawberry were observed when $7 \mathrm{~N}-5 \mathrm{P}-15 \mathrm{~K}$ was used as fertilizer, 3.49 and $3.71 \mathrm{~g} /$ plant respectively, for the two concentrations. At a concentration of $0.5 \%$, good growth of strawberry and a moderate VAM infection were reported (Fig. 2).

The number of runners per plant was highest at the highest dry weight: 3.8 and 4.0 for the compound fertilizer $7 \mathrm{~N}-5 \mathrm{P}-15 \mathrm{~K}$ (Table 3). In unfertilized control plants there were no runners at all. The length of the leaf stalk averaged $11.2 \mathrm{~cm}$ and $10.5 \mathrm{~cm}$, respectively for the three largest leaves when $7 \mathrm{~N}-5 \mathrm{P}-15 \mathrm{~K}(0.5$ and $1.5 \mathrm{~g} / \mathrm{l})$ was used as fertilizer.

\section{Experiment 3}

The level of dolomite lime applied had no significant effect on the appearance of Glomus mosseae spores in the pots with maize (Fig. 3) after 113 days. Similarly to experiments 1 and 2, spores appeared very abundantly in the treatment with bone meal + Hewitt (79 P). However, the dry 


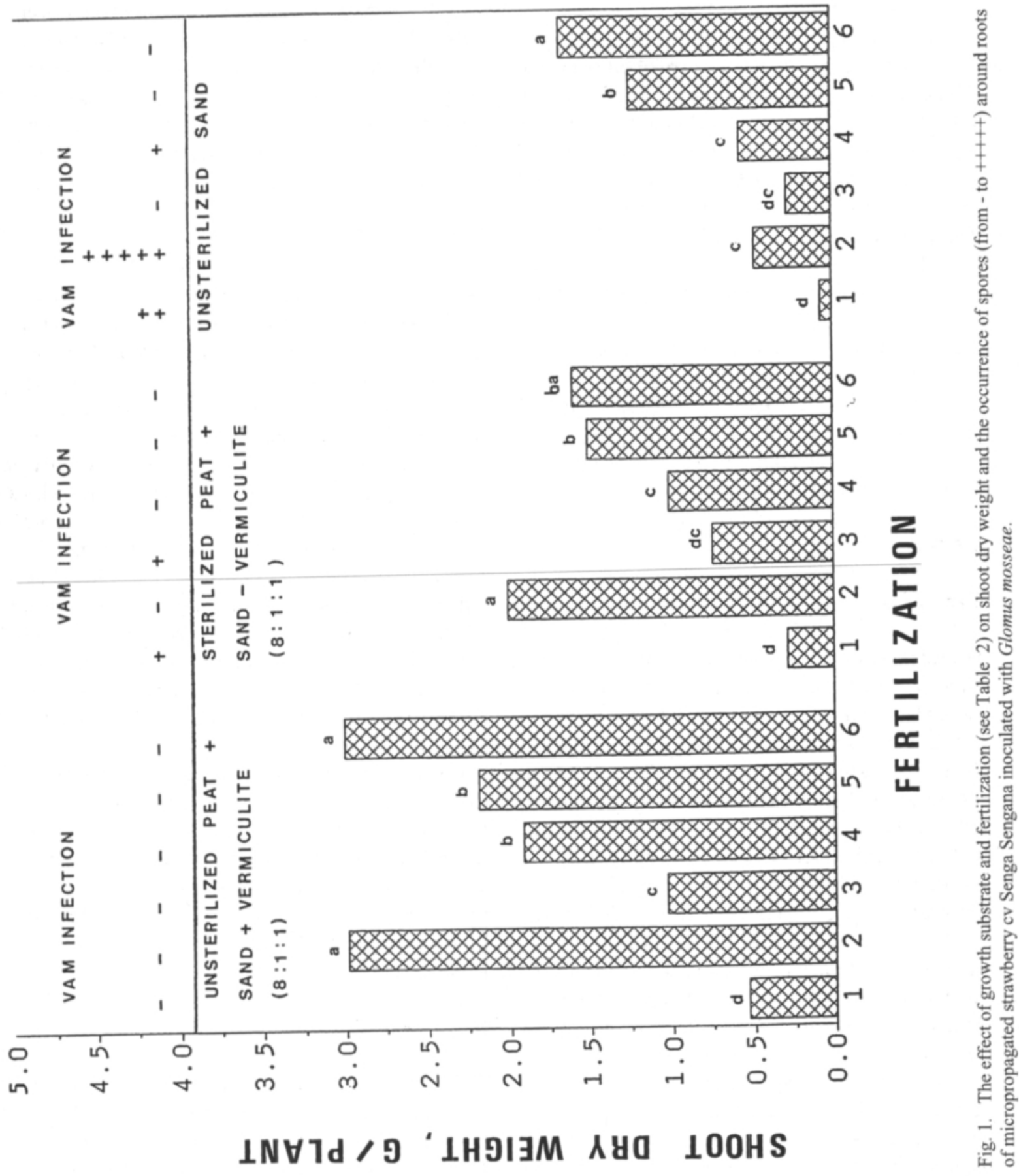




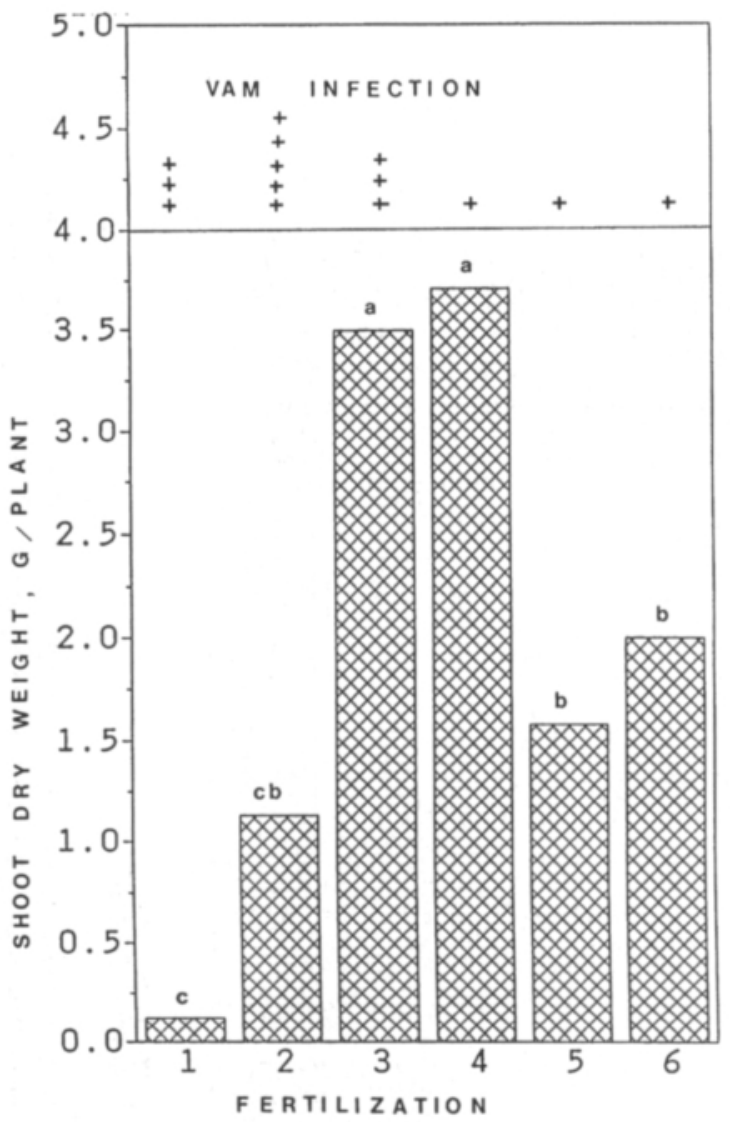

Fig. 2. The effect of fertilization (see Table 2) on shoot dry weight and the occurrence of spores (from - to $++1++$ ) around roots of of micropropagated strawberry cv Senga Sengana inoculated with Glomus mosseae. Sand substrate. Bars marked with the same letter do not differ significantly at $\mathrm{P}=0.05$.

Table 3. The effect of fertilization (see table 2) on the numbers of runners and the average length of the three longest leaf stalks in micropropagated strawberry cv. Senga Sengana inoculated with Glomus mosseae.

\begin{tabular}{lcc}
\hline Fertilization & $\begin{array}{l}\text { Number of } \\
\text { runners/plant }\end{array}$ & $\begin{array}{l}\text { Height of } \\
\text { leaf stalk, cm }\end{array}$ \\
\hline 1 & $0^{\mathrm{d}}$ & $2.4^{\mathrm{d}}$ \\
2 & $1.0^{\text {cd }}$ & $5.1^{\mathrm{c}}$ \\
3 & $3.8^{\mathrm{a}}$ & $11.2^{\mathrm{a}}$ \\
4 & $4.0^{\mathrm{a}}$ & $10.5^{\mathrm{b}}$ \\
5 & $1.5^{\mathrm{bb}}$ & $9.6^{\mathrm{b}}$ \\
6 & $2.3^{\mathrm{b}}$ & $9.2^{\mathrm{b}}$ \\
\hline
\end{tabular}

Values in columns marked with the same letter do not differ at $\mathrm{P}=0,05$ (Duncan) weight of maize plants in this treatment was low, varying between 2.62 and $4.34 \mathrm{~g} /$ plant after different liming treatments. In pots given the compound fertilizer $7 \mathrm{~N}-5 \mathrm{P}-15 \mathrm{~K}$ (25 and $75 \mathrm{P})$, infection was moderate to abundant, while the total dry weight of maize was considerably higher than in the bone meal + Hewitt treatment, varying from 1.87 to $12.04 \mathrm{~g}$ dry weight/plant. Maize growth was abundant after application of the liquid fertilizer $14 \mathrm{~N}-5 \mathrm{P}-21 \mathrm{~K}(25$ and $50 \mathrm{P})$, the total dry weight being $16.51-18.59 \mathrm{~g} /$ plant at the concentration $0.1 \%$. At the concentration $0.05 \%$ liquid fertilizer a moderate to even abundant spore occurrence was noticed, while at the concentration $0.1 \%$ spores did not occur or only very poorly.

\section{Experiment 4}

Inoculation with VAM had on average a significant influence on total dry matter of arctic bramble. In 'Mespi', all the fungal strains used increased the total dry weight as compared to the control. The effect was greatest after inoculation with isolate 4 . In 'Pima', isolate 3 gave the highest total dry weight (Table 5). Isolate 2 decreased the yield as compared to the control.

Due to the spread of the introduced VAM fungi, almost all control plants of both 'Mespi' and 'Pima' exhibited root infection ( Fig . 4). In the sand substrate ( B ), control plants had a lower percentage of VAM-infection than in the peat-based substrates where plants showed a better growth. On average there were only minor differences between the percentages of VAM infection in roots of arctic bramble growing on different substrates with $\mathrm{P}$-contents varying from very low (substrate B) up to $27 \mathrm{mg} \mathrm{P} / 1$ (C), $44 \mathrm{mg} \mathrm{P} / 1$ (B) and $58 \mathrm{mg} \mathrm{P} / 1$ substrate. However, the highest infection rates occurred on the sand substrates both for 'Mespi' and 'Pima'. In contradiction to the percentage of root infection, the introduced VAM fungi sporulated moderately or abundantly only in the sand substrate (Fig. 4). The sporulation of strain 3 , however, was neglictible or very poor also in this substrate. VAM-inoculation greatly 


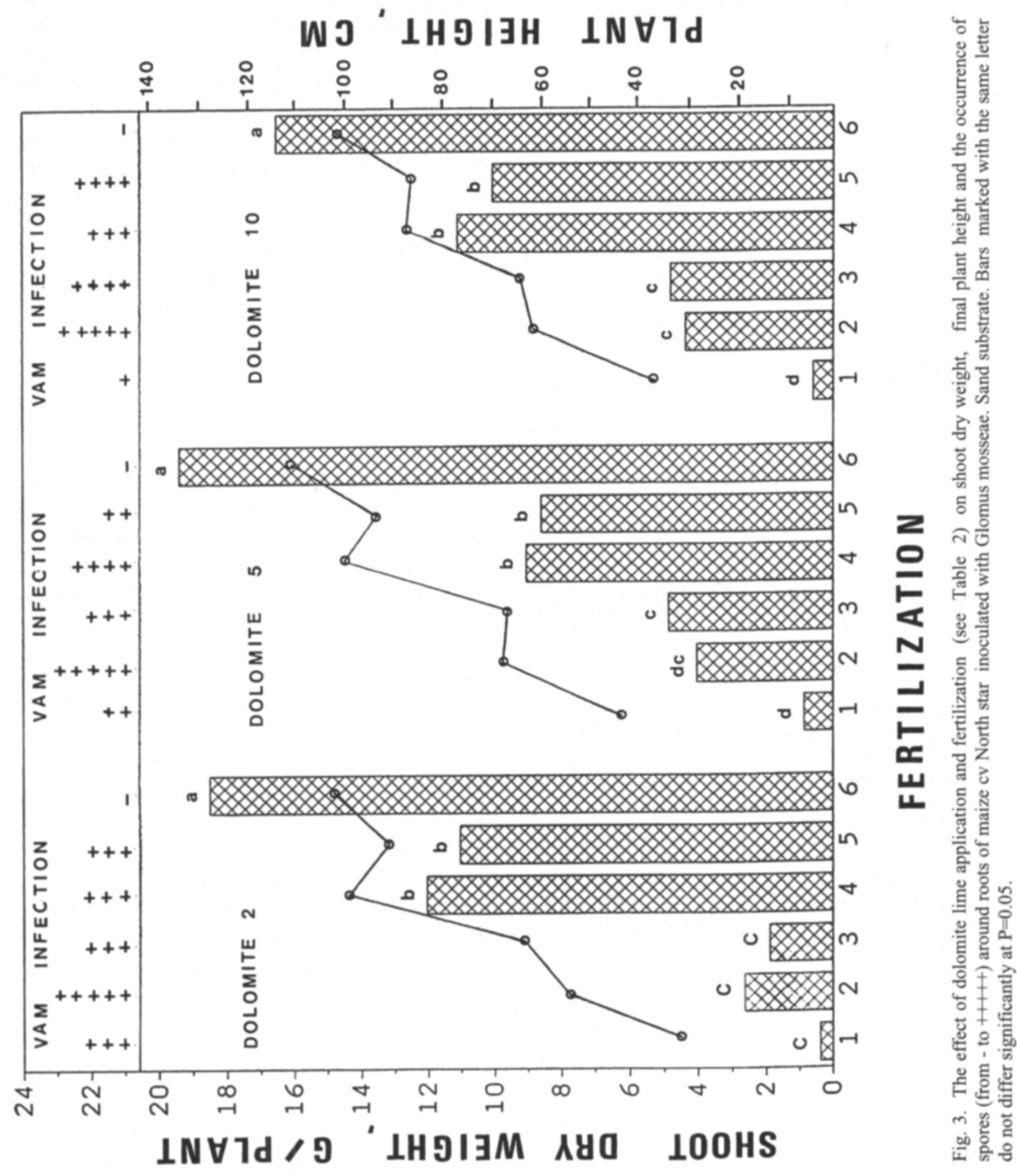



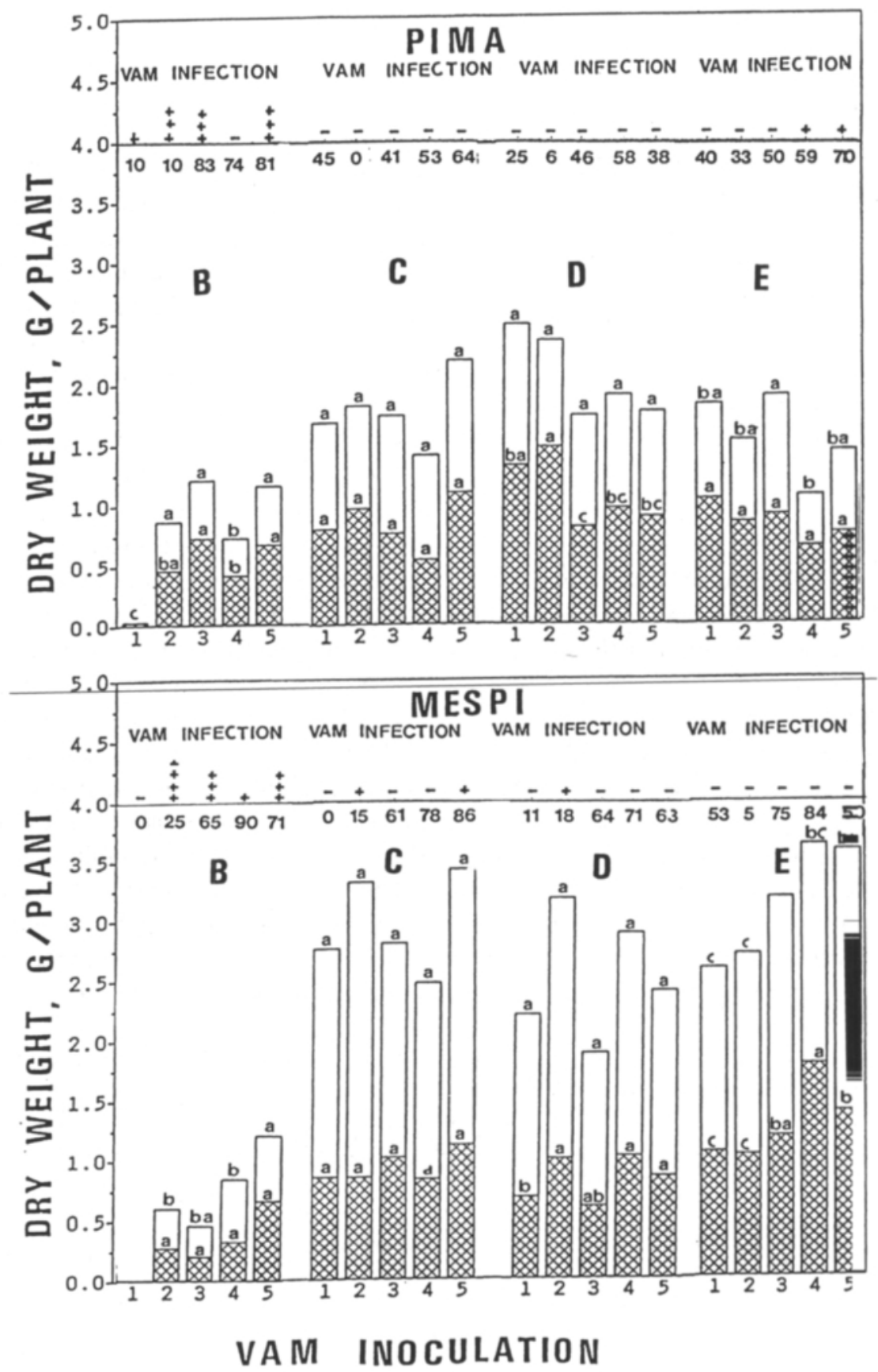

Fig. 4. The effect of growth substrate (see Table 2) and VAM inoculation (1, 2, 3, 4, 5: uninoculated, G. mosseae and G. spp 3, 4 and 4, respectively) on total dry weight, VAM infection and the occurrence of spores (from - to $++1+$ ) around roots of micropropagated arctic bramble cvs Mespi and Pima. Whole bar indicates total dry weight. Part of bar marked with crosshatched lines indicates root dry weight. Bars marked with the same letter do not differ significantly at $\mathrm{P}=0.05$. Numbers below horizontal line indicate percentage of root infection. 
Table 4. The effect of vesicular-arbuscular mycorrhizal inoculation on the percentage of surviving plants of arctic bramble cvs 'Mespi' and 'Pima' on a sand substrate after 195 days.

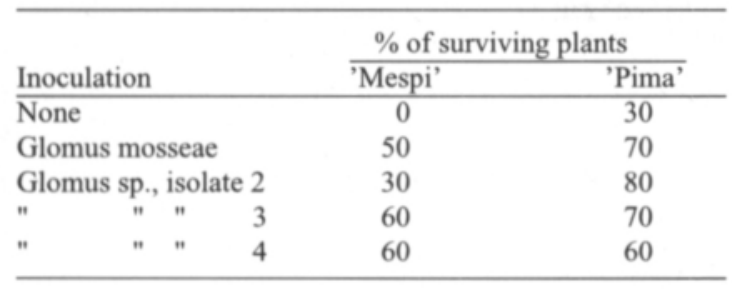

increased the percentage of surviving arctic brambles on the sand substrate (Table 4).

\section{Discussion}

Very abundant VAM sporulation was observed in experiments 1, 2 and 3 both in strawberry and maize in a sand substrate fertilized with bone meal, which gave a calculated $\mathrm{P}$ content of $79 \mathrm{mg}$ slowly soluble $\mathrm{P} / 1$. The result is in agreement with other studies (GerdemanN 1968, Mosse 1973, MeNGE et al. 1978) according to which mycorrhizal infection best takes place under P-limiting conditions. Despite good mycorrhizal infection, the plants growing on a sand substrate fertilized with bone meal were always inferior in size to the plants given mineral fertilizers, which on average had only a poor to moderate VAM infection. A compromise must therefore be made in order to produce plants of sufficient size, which at the same time are mycorrhizal. In strawberry grown on a sand substrate, the compound fertilizer $7 \mathrm{~N}-5 \mathrm{P}-15 \mathrm{~K}$ used at a concentration of $0.5 \mathrm{~g} / \mathrm{l}$, giving a $\mathrm{P}$ content of $25 \mathrm{mg} / \mathrm{l}$, seems to meet these requirements rather well (experiment 2). Maize achieved a moderate growth and VAM sporulation by applying $7 \mathrm{~N}-5 \mathrm{P}-15 \mathrm{~K}$ at a concentration of 1.5 $\mathrm{g} / \mathrm{l}$ which gives a $\mathrm{P}$ content of $75 \mathrm{mg} / \mathrm{l}$, or by applying the liquid fertilizer $14 \mathrm{~N}-5 \mathrm{P}-21 \mathrm{~K}$ at a 0.05 $\%$ concentration weekly.

Sporulation occurred also at fairly high levels of available substrate $P$. The highest phosphorus content, where sporulation of the introduced VAM fungi occurred, was observed at $111 \mathrm{mg} \mathrm{P} / 1$ substrate for strawberry in experiment 1 , which is in agreement with the findings by GERDEMANN (1970) who claims that many crops in the Mid-West of the USA remained highly mycorrhizal despite high soil fertility. In experiment 3 , sporulation of VAM was moderate in maize at a phosphorus level of $75 \mathrm{mg} / \mathrm{l}$ soil. This observation supports the studies by FAIRCHILD and MILLER (1990) and KoTHARI et al. (1991) according to which VAM infection of maize was observed even after amendments with $\mathrm{P}$ of $100 \mathrm{mg} / \mathrm{kg}$ soil or more.

On the peaty substrate in experiment 1 , maximum growth was achieved at a phosphorus

Table 5. Significance of F-values in the analysis of variance for dry weight, plant height and mycorrhizal root infection of arctic bramble.

\begin{tabular}{lccclc}
\hline \multirow{2}{*}{$\begin{array}{l}\text { Source } \\
\text { of variation }\end{array}$} & \multicolumn{3}{c}{ Significance of F-value } \\
\cline { 2 - 6 } & Shoot & Root & Total & $\begin{array}{l}\text { Plant } \\
\text { height }\end{array}$ & $\begin{array}{l}\text { Root } \\
\text { infection }\end{array}$ \\
A. Cultivar & $* * *$ & NS & $* * *$ & $* * *$ & NS \\
B. Substrate & $* * *$ & $* * *$ & $* * *$ & $* * *$ & NS \\
C. VAM & NS & $* *$ & $* *$ & NS & $* * *$ \\
A x B & $* * *$ & $* * *$ & $* * *$ & $* * *$ & NS \\
A x C & NS & $* * *$ & $* *$ & NS & $* *$ \\
B x C & NS & $* * *$ & $* *$ & NS & $* *$ \\
A x B x C & NS & NS & NS & NS & NS \\
\hline
\end{tabular}

$\begin{array}{ll}* & \mathrm{P}<0.05 \\ * * & \mathrm{P}<0.01 \\ * * * & \mathrm{P}<0.001 \\ \text { NS } & \text { Non-significant }\end{array}$


content of $165 \mathrm{mg} / \mathrm{l}$ when bone meal was used together with fertilized peat. Peat together with mineral fertilizers giving phosphorus contents varying from 111 to $161 \mathrm{mg} / \mathrm{l}$ substrate yielded a significantly slower growth. This indicates a mycorrhizal effect of the bone meal treatment despite no visible sporulation. However, root infection in the form of appressoria, arbuscules or vesicles may have been present. These were not determined in the experiment.

This is the first report of VAM infection in arctic bramble. However, infection is not surprising because the Rosaceae family is found to be very mycorrhizal (HARLEY and HarLeY 1987). As the sand substrate and bone meal combination was not used for arctic bramble, the results cannot be directly compared with those obtained on strawberry and maize. However, three out of four VAM strains sporulated moderately to abundantly only on the unfertilized sand substrate. On the peaty substrates, with $P$ contents ranging from 27 to $58 \mathrm{mg} /$, sporulation was very poor and occasional although growth was abundant. These findings indicate that peat suppresses VAM sporulation in arctic bramble. However, there were only minor differences in the percentage of root infection of arctic bramble growing on peaty or sand substrate. In experiment 1, sporulation of $\mathrm{G}$ mosseae was also negligible or very poor in strawberry growing on peaty substrates. However, the substrates cannot be compared directly with each other, because the peaty ones were much richer ( $\mathrm{P}$ from 86 to $165 \mathrm{mg} / \mathrm{l}$ ) than the sand substrates ( $P$ up to $79 \mathrm{mg} / \mathrm{l}$ ).

With respect to commercial growing and VAM inoculation of strawberry, maize and arctic bramble, the results of this investigation are highly preliminary. The nutrient levels of different substrates were only calculated and not measured. The difference in buffering capacities between peaty and sandy substrates was not taken into consideration. Some substrates were steam sterilized, the effect of which on nutrient availability, especially on nitrogen, was not estimated. The range of fertilizers studied was narrow. For example, slowrelease compound mineral fertilizers such as osmocote were not tested at all although there are indications that this type of fertilizer could provide the best compromise in producing well growing mycorrhizal plants (MARONEK et al. 1980, WATERER and Coltman 1988).

\section{References}

Chavez, Mc.G. \& Ferrara-Cerrato, R. 1990. Effect of vesicular-arbuscular mycorrhizae on tissue culture-derived plantlets of strawberry. HortSci. 25: 903-905.

COOPER, K. M. 1982. Mycorrhizal fungi - their role in plant establishment. Proc. Int. Pl. Prop. Soc. 32: 396-404.

DAFT, M.J. 1991. Influences of genotypes, rock phosphate and plant densities on mycorrhizal development and the growth responses of five different crops. Agriculture, Ecosystems and Environment 35: 151-169.

- \& OKusAnYA, B.O. 1973. Effect of Endogone mycorrhiza on plant growth. VI. Influence of infection on the anatomy and reproductive development in four hosts. New Phytol. 72: 1333-1339.

DUNNE, M.J. \& FitTER, A.H. 1989. The phosphorus budget of a field-grown strawberry (Fragaria x ananassa cv. Hapil) crop: evidence for a mycorrhizal contribution. Ann. Appl. Biol. 114: 185-193.

FAIRCHILD, M.H. \& Miller, G.L. 1990. Vesicular-arbuscular mycorhizas and the soil-disturbance-induced re- duction of nutrient absorption in maize. III. Influence of P amendments to soil. New Phytol. 114: 641-650.

FITTER, A.H. 1988. Water relations of red clover Trifolium pratense $\mathrm{L}$. as affected by VA mycorrhizal infection and phosphorus supply before and during drought. J. Exp. Bot. 39: 595-603.

GERDEMANN, J.W. 1968. Vesicular-arbuscular mycorrhizae and plant growth. Ann. Rev. Phytopathol. 6: 397-418.

- 1970. The significance of VA mycorrhizae in plant nutrition. In "Root diseases and soil borne pathogens", (eds.) Tousson, T.A., Bega, R.V. \& Nelson, P.E. Univ. of California Press, Berkeley, 125.

GiovannetTI, M. \& Mosse, B. 1980. An evaluation of techniques for measuring vesicular-arbuscular mycorrhizal infection in roots. New Phytol. 84: 489-500.

HaRley, J.L. \& HaRley, E.L. 1987. A check-list of mycorrhiza in the British flora. New Phytol.(suppl.) 105: 1-102.

HARLEY, J. L. 1965. Mycorrhiza. In: "Ecology of soil- 
borne plant pathogens. Prelude to biological control" (eds.) Baker, K. F. \& Snyder, W. C. University of California press. $522 \mathrm{p}$.

HewITT, E.J. 1952. Sand and water culture methods used in the study of plant nutrition. Tech. Comm. 22. Farnham Royal. Commonwealth Agric. B. Bucks.

Holevas, C. D. 1966. The effect of vesicular-arbuscular mycorrhiza on the uptake of soil phosphorus by strawberry (Fraqaria sp. var. Cambridge favourite). J. Hort. Sci. 4i: 57-64.

КнаN, A. G. 1972. The effect of vesicular-arbuscular mycorrhizal associations on growth of cereals. I. Effects on maize growth. New Phytol. 71: 613-

Kiernan, J.M., Hendrix, J.W., Stoltz, L.P. \& MaroneK, D.M. 1984. Characterization of strawberry plants produced by tissue culture and infected with specific mycorrhizal fungi. Hort. Sci. 19: 883-885.

Kothari, S.K., MARSCNER, H. \& GeORGE, E 1991. Effect of VA mycorrhizal fungi and rhizosphere microorganisms on root and shoot morphology, growth and water relations in maize. New Phytol. 116:303-311.

MaroneK, D.W., Hendrix, J.W. \& Kiernan, J. 1980. Differential growth response to the mycorrhizal fungus Glomus fasciculatus of southern magnolia and Bar Harbor junipers grown in containers in composted hardwood bark-shale. J. Am. Soc. Hort. Sci. 105: 206-208.

Menge, J.A., Johnson, E.L.V. \& Platt, R.G. 1978. Mycorrhizal dependency of several citrus cultivars under three nutrient regimes. New Phytol. 81: 553-559.

Mosse, B. 1973. Advances in the study of vesicular-ar- buscular mycorrhiza. Ann. Rev. Phytopathol. 11: 171-196.

-1986. Mycorrhizae in a sustainable agriculture. Biol. Agric. \& Hort. 3: 191-209.

Robertson, W.J., BOyle, C.D. \& Brown, H.L. 1988. Endomycorrhizal status of certified strawberry nursery stock. J. Am. Soc. Hort. Sci. 113: 525-529.

Ross, J.P. \& HARPER, J.A. 1970. Effect of Endogone mycorrhiza on soybean yields. Phytopath. 60: 15521556.

SCHÖEPP, H., DEHN, B. \& StICHER, H. 1987. Interaktionen zwischen VA-Mycorrhizen und Schweermetallbelastungen. Angew. Bot. 61: 85-96.

WATERER, D.R. \& COLtMAN, R.R. 1988. Effects of controlled- release phosphorus and inoculum density on the growth and mycorrhizal infection of pepper and leek transplants. HortSci. 23: 620-622.

Werner, M.R., Kluson, R.A. \& Gliessman, S.R. 1990. Colonization of strawberry roots by VA mycorrhizal fungi in agroecosystems under conventional and transitional organic management. Bio1. Agric. \& Hort. 7: 139-151.

\section{Manuscript received November 1991}

Mauritz Vestberg

Agricultural Research Centre of Finland

Laukaa Research and Healthy Plant Unit

Juntula, SF-41340 Laukaa, Finland

\title{
SELOSTUS
}

\section{Kasvualustan ja lannoituksen vaikutus VA-mykorritsasieniymppäyksen onnistumiseen kolmella kasvilla}

\author{
MAuritz VestberG \\ Maatalouden tutkimuskeskus
}

Vesikkeli-arbuskeli mykorritsasienten (VAM) ymppäystä eri kasvualustoilla kasvaviin ja eri lannoitteita saaneisiin mansikkaan, mesimarjaan ja maissiin tutkittiin astiakokeissa Maatalouden tutkimuskeskuksen Keski-Suomen tutkimusasemalla ja tervetaimiasemalla. Kasvualustat olivat hiekkaa tai turpeen (B1 tai B2) ja hiekan seoksia. Lannoitteina käytettiin luujauhoa, jonka fosfori on hitaasti liukenevassa muodossa, Puutarhan Y-lannosta 2 ja puutarhan täyslannosta. Mansikkaan ja maissiin ympätty mykorritsasieni oli Englannista tuotettu Glomus mosseae. Mesimarjakokeessa kokeiltiin myös kolmea suomalaista Glomus-sienikantaa. Luujauholla lannoitetulla hiekka-alustalla kaikki tutkitut kasvit saivat nopeasti runsaan VAM-infektion. Kun hiekkaalusta oli lannoitettu văkilannoitteilla VAM-infektio jäi vă- häiseksi. Turvealustoilla infektio jäi niinikään alussa vähäiseksi, mutta pitkäaikaisessa kokeessa kuten mesimarjakokeessa (195 päivää) mesimarjan juurten VAM-pitoisuuksissa ei kokeen lopussa ollut eroja turve- ja hiekka-alustan välillä.

Vaikka kasvit olivat hiekka-alustalla runsaasti mykorritsallisia jäivăt ne kooltaan pieniksi verrattuna kivennăislannoitteita saaneisiin kasveihin. Käytännön mykorritsaymppäyksessä täytyy tehdä kompromissi näiden äärimmäisyyksien vălillä. lannoitusstrategian tulee taata samanaikaisesti hyvă kasvu ja tyydyttävä VAM-infektio. Käytetyistă lannoitteista Puutarhan Y-lannos $2(0.5 \mathrm{~g} / 1$ kasvualustaa) tãytti nämä edellytykset melko hyvin. 